Resultados: Para as resinas Kooliner e Ufi Gel Hard não foram obtidas diferenças estatisticamente significativas nos valores de resistência à flexão entre grupos com diferentes concentrações de clorexidina ( $p>0,05)$. No entanto, para a resina Probase Cold, o grupo 5\% apresentou um valor de resistência à flexão inferior ao grupo controlo $(p=0,033)$.

Conclusões: As concentrações de clorexidina iguais a 1\%, $2,5 \%, 5 \%$ e 7,5\% para a resina Kooliner, de 1\%, 2,5\%, 5\%, 7,5\% e $10 \%$ para a resina Ufi Gel Hard e de $1 \%$ e $2,5 \%$ para a resina Probase Cold não afetaram a resistência à flexão das resinas de rebasamento avaliadas, após estas serem sujeitas a envelhecimento térmico equivalente a um mês na cavidade oral. http://doi.org/10.24873/j.rpemd.2018.11.435

\section{\#110 Resinas acrílicas com clorexidina envelhecidas - estudos de adesão e energia de superfície}

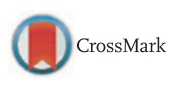

Natália Costa*, Joana Costa, Jaime Portugal, Ana Bettencourt, Cristina Bettencourt Neves

Faculdade de Farmácia da Universidade de Lisboa; Faculdade de Medicina Dentária da Universidade de Lisboa

Objetivos: Avaliar o efeito da incorporação de diferentes concentrações de clorexidina (CHX), na resistência adesiva ao corte e energia de superfície, de três resinas acrílicas de rebasamento, sujeitas a um processo de envelhecimento.

Materiais e métodos: Para a determinação da resistência adesiva, foram fabricadas 120 placas de resina de base de prótese, submetidas a 2500 ciclos de termociclagem $\left(5 .^{\circ} \mathrm{e}\right.$ $55 .{ }^{\circ} \mathrm{C}, 40$ segundos de imersão). As placas foram divididas em 12 grupos experimentais $(n=10)$, de acordo com a resina a ser utilizada no rebasamento: Kooliner, Ufi Gel Hard, Probase Cold, e a concentração de CHX incorporada (Kooliner: 0\%; 2,5\%; 5\%; 7,5\%; Ufi Gel Hard: 0\%; 2,5\%; 5\%; 7,5\%; 10\%; Probase Cold: $0 \% ; 2,5 \%$; $5 \%$ ). A resina de rebasamento foi adicionada e os espécimes foram submetidos a 1000 ciclos térmicos $\left(5 .^{\circ}\right.$ e $55 .{ }^{\circ} \mathrm{C}, 40$ segundos de imersão). Os testes de resistência adesiva a tensão de corte foram realizados (Instron; $1 \mathrm{~mm} / \mathrm{min} ; 1 \mathrm{KN}$ ) e as superfícies classificadas segundo o tipo de falha de união em: adesiva, mista ou coesiva. Para o teste de energia de superfície, foram elaborados 63

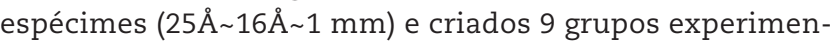
tais $(n=7)$ de acordo com as resinas de rebasamento e concentração de CHX incorporada (Kooliner: 0\%; 2,5\% e 5\%; Ufi Gel Hard: 0\%; 5\% e 7,5\%; Probase Cold: 0\%; 2,5\% e 5\%). Após termociclagem (1000 ciclos; $5 .^{\circ}$ e $55{ }^{\circ} \mathrm{C}$, 40 segundos de imersão) os espécimes foram testados com um tensiómetro de Kruss, através da técnica da placa de Wilhelmy. Os dados da resistência adesiva foram analisados estatisticamente com testes não paramétricos (Kruskal-Wallis; Man-Whitney; Bonferroni; $\alpha=0,05$ ).

Resultados: A concentração de CHX não influenciou de forma significativa os espécimes de Kooliner e Ufi Gel Hard ( $p>0,05)$. Relativamente ao Probase Cold, a incorporação com $5 \%$ de CHX conduziu a uma diminuição dos valores de adesão $(p=0,033)$, comparativamente ao controlo ( $0 \% \mathrm{CHX})$. Não foram encontradas diferenças estatisticamente significativas $(p>0,05)$ em qualquer um dos materiais estudados, respeitante à energia de superfície.

Conclusões: A incorporação de CHX, não parece afetar a resistência adesiva do Kooliner e Ufi Gel Hard mas influencia negativamente a adesão do Probase Cold com 5\% de CHX, após um processo de envelhecimento; não parece afetar a energia de superfície das três resinas.

http://doi.org/10.24873/j.rpemd.2018.11.434

\#111 Avaliação da atividade antimicrobiana de óleos de origem vegetal em bactérias cariogénicas

Patrícia Pratas*, Cristina Manso, Helena Barroso

Centro de Investigação Interdisciplinar Egas Moniz - Instituto Universitário Egas Moniz

Objetivos: Os colutórios antimicrobianos atuam como adjuvantes dos cuidados diários e impedem de modo eficaz a colonização de microrganismos. No entanto, o aumento da prevalência dos efeitos colaterais de muitos medicamentos sintéticos e o aparecimento de resistências por parte dos microrganismos tem encorajado os cientistas a pesquisar alternativas complementares, à base de plantas. Pretende-se com este estudo avaliar a capacidade inibitória in vitro do óleo de coco e do óleo de sésamo sobre bactérias cariogénicas, como Streptococcus mutans, Lactobacillus spp, e ainda Streptococcus mitis.

Materiais e métodos: Os ensaios foram efetuados de acordo com os critérios do Clinical and Laboratory Standards Institute (CLSI), pelo método de difusão em disco, pelo método de diluição em meio líquido e ainda pelo método de microdiluição. No método de difusão em disco os microrganismos foram inoculados em meio de cultura (Mueller-Hinton com sangue para Streptococcus e Rogosa agar para Lactobacillus), aplicando-se de seguida o óleo de coco e o óleo de sésamo sobre discos estéreis. Após $24 \mathrm{~h}$ e $48 \mathrm{~h}$ foi avaliada a ausência ou não de crescimento bacteriano. Nos métodos de diluição, a suspensão bacteriana foi adicionada ao óleo, em volumes iguais, e foi observada/quantificada a ausência ou presença de crescimento. Foram utilizadas suspensões bacterianas com concentrações entre $10^{\wedge} 8 \mathrm{ufc} / \mathrm{ml}$ e $10 \mathrm{ufc} / \mathrm{ml}$.

Resultados: Nenhum dos óleos testados apresentou atividade antimicrobiana contra os microrganismos testados. Este resultado foi consistente independentemente do método utilizado.

Conclusões: Através dos ensaios in vitro efetuados foi possível verificar que o óleo de coco e o óleo de sésamo não apresentam atividade antimicrobiana direta contra bactérias cariogénicas. Alguns autores defendem a capacidade antimicrobiana do óleo de coco devido ao efeito de saponificação, emulsão e ação de limpeza mecânica. O bochecho com o óleo forma uma camada viscosa impedindo a adesão das bactérias ao dente. Também a reação dos constituintes do óleo com a saliva dá origem a compostos que impedem o desenvolvimento microbiano. No entanto todos estes efeitos são indiretos. Com este estudo, demonstrámos que a ação antimicrobiana direta não se verifica.

http://doi.org/10.24873/j.rpemd.2018.11.433 